\title{
LEAN TOOLS PROPOSAL TO MITIGATE DELAYS AND COST OVERRUNS IN CONSTRUCTION PROJECTS
}

\author{
Adriana Gómez-Cabrera ${ }^{1}$, Luis A. Salazar ${ }^{2}$, \\ José L. Ponz-Tienda ${ }^{3}$, and Luis F. Alarcón ${ }^{4}$
}

\begin{abstract}
Construction projects are carried out under the triple constraint of cost, time, and scope, as stated in the project management literature. However, time and cost deviations in the construction industry are frequent, and their magnitude in many cases is considerable, generating harmful consequences. This paper developed a literature review to examine 33 research papers published since 1988 in the Web of Science database to identify the main factors causing these deviations, demonstrating that there is no evidence that it is a problem exclusive from a region, country, or project type. A list of 74 factors has been identified from the top ten reported in each paper. The factors were grouped, taking into account their origin. Simultaneously through literature review, tools, methods, and approaches of Lean Construction were also identified, and after an analysis of its nature, these tools were assigned to the previously identified factors considering the possibilities to mitigate their effects. For more than $88 \%$ of the identified factors, a Lean tool, method, or approach was identified, demonstrating that both topics are related, and the body of literature developed must be integrated.
\end{abstract}

\section{KEYWORDS}

Delays, Cost overruns, Construction projects, Lean tools, Lean plan

\section{INTRODUCTION}

Delays and cost escalations in construction projects are problems that have been approached by many researchers through time, developing a significant body of literature.

This paper presents a literature review that examines 33 research papers published from 1988 until 2018 in the Web of Science database demonstrating that these problems are still prevalent. A substantial number of studies worldwide have addressed this topic

1 PhD Candidate, Civil and Envir. Engineering. Department, Universidad de Los Andes, and Professor, Civil Engineering Department, Pontificia Universidad Javeriana, +(57) 3155135715, ca.gomez1@uniandes.edu.co, orcid.org/0000-0001-5092-2191

2 PhD Candidate, Department of Construction Engineering and Management, Pontificia Universidad, Católica de Chile, and Professor, Construction Engineering, Faculty of Engineering, Universidad Andres Bello, Santiago, Chile, +56 22661 8346, lasalaza@uc.cl, orcid.org/0000-0001-7339-8935

$3 \mathrm{PhD}$, Assistant Professor, Civil and Envir. Engineering, Dept., Director of the Engineering and Construction Management Research Group, Univ. de Los Andes, Bogotá, Colombia, (57-1) 3324312, jl.ponz@uniandes.edu, orcid.org/0000-0001-6513-8826

4 Professor, Department of Construction Engineering and Management, Pontificia Universidad Católica, de Chile, Santiago, Chile, +56 22354 7165, lalarcon@,ing.puc.cl, orcid.org/0000-0002-9277-2272 
to reveal the magnitude. It has been established that 9 of 10 transport infrastructure projects around the world present this deviation (Flyvbjerg et al. 2002). In Australia, a study revealed a mean cost overrun of $12.22 \%$, including civil engineering and construction projects (Love et al. 2013). More recently in Colombia, it was reported that public infrastructure projects had experienced delays as high as $342 \%$ and cost overruns as high as $110 \%$ (Vallejo-Borda et al. 2015). A significant body of the literature have been developed, but there is a need to summarize and aggregate the literature to find out the actual status of the field and to propose tools, methods and approaches to mitigate the effects.

In this paper, a Lean Implementation Plan is proposed to identify Lean tools, methods, and approaches that allow mitigation of the factors causing delays and cost overruns in construction projects. These Lean tools have been extracted through a literature review, according to the State of Art and Practice (Arroyo et al. 2019; Castiblanco et al. 2019; Farzad and Cameron 2019; Giménez et al. 2019; Gómez-Sánchez et al. 2019; Hackler et al. 2019; Ryan et al. 2019; Salazar et al. 2019; Skaar 2019; Taggart et al. 2019).

\section{RESEARCH METHODOLOGY}

This section describes the research methodology developed by the authors of this document. The research procedure consisted of: (1) Initial literature search about deviations and cost overruns in construction projects; (2) Perform an in-depth qualitative analysis of the documents; (3) Identification of 74 relevant factors; (4) Classification of the 74 factors in 6 groups; (5) Search for the most used Lean Construction tools; (6) Short definition of each selected tool; (7) Assignment of a specific Lean tool to mitigate each of the factors (8) Proposal for an implementation plan.

\section{IDENTIFICATION OF FACTORS CAUSING DELAYS AND COST OVERRUNS IN CONSTRUCTION PROJECTS}

To obtain an overall picture of the research problem, a systematic and extensive search was conducted. The objective consisted of gathering peer-reviewed articles related to delays and cost overruns in construction projects from the Web of Science and Scopus databases.

A general search on the Web of Science Core Collection was developed. The search was refined, limiting the category to "Engineering civil" and "Construction building technology." The search results were refined to include articles in English published in journals with an assigned quartile, reporting factors generating delays, and cost overruns in construction projects around the world. Papers excluded were those focusing on the effects or implications of the research topic. Then, a review of the titles and abstracts for each one of the papers found in the initial search was developed by screening the selected papers. This review verified that the papers met the goal of the research and eliminated those that did not apply. A previous study developed was considered (Gómez-Cabrera et al., 2019).

Then, the data collection included a deep-systematic reading of the selected papers, extracting information like journal, year, country (refers to the country where the projects analyzed in the paper were developed), type of deviation reported (Cost, time or both), type of projects considered (Buildings, Infrastructure, both or not available - NA), and factors reported as generators of cost and time overruns in construction projects (as included in most of the papers). At this point, the top ten factors were extracted from each 
article, although not all articles included at least ten. Seventy-four factors were identified and classified into six groups (see Table 2). The references analyzed in this research included papers from different regions, those are cited according to the number of documents: China (Lo et al. 2006) (Chiu and Lai 2017) (Chan and Kumaraswamy 1996) (Wang et al. 2018), Iran (Fallahnejad 2013) (Derakhshanalavijeh and Teixeira 2017) (Shahsavand et al. 2018), Nigeria, (Okpala and Aniekwu 1988) (Elinwa and Joshua 2001) (Aibinu and Odeyinka 2006), Turkey (Kazaz et al. 2012) (Gunduz et al. 2013) (Gunduz et al. 2015), Australia (Doloi 2013) (Creedy et al. 2010), India (Iyer and Jha 2006) (Doloi et al. 2012), Vietnam (Le-Hoai et al. 2008) (Kim et al. 2017), Benin (Akogbe et al. 2013), Burkina Faso (Bagaya and Song 2016), Cambodia (Santoso and Soeng 2016), Denamrk (Larsen et al. 2016), Egypt (Abd El-Razek et al. 2008), Malawi (Kamanga and Steyn 2013), Pakistan (Batool and Abbas 2017), Palestine (Mahamid et al. 2012), Saudi Arabia (Assaf et al. 1995), Tanzania (Sambasivan et al. 2017), United Arab Emirates (Mpofu et al. 2017), Zambia (Kaliba et al. 2009), and other including diferent countries (Ahsan and Gunawan 2010) (Ruqaishi and Bashir 2015).

Figure 1 shows the number of publications per deviation reported and project type. In Figure 1-left, the type of deviation reported in the articles is included, TI: Time deviation, CO: Cost deviation, and CO/TI: Both. Figure 1-right consists of the type of project included: BU-Buildings, IN- Infrastructure, BU/IN - for both and NA - Not Available.
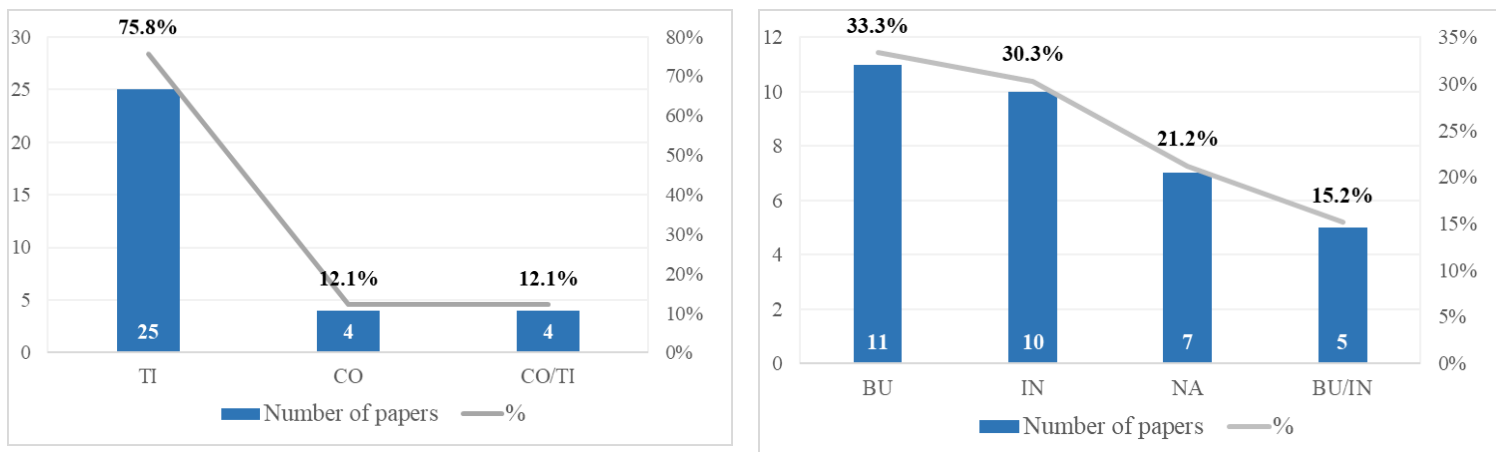

Figure 1: Number of publications per deviation reported and project type

\section{LEAN IMPLEMENTATION PROPOSAL}

Following the problems mentioned above and the consequences they imply for the construction industry worldwide, the authors offer a Lean Implementation Plan (LIP). This plan is based on the study of the state of the art and practice, proposing to each factor a particular Lean tool, method, or approach that can mitigate its effects.

\section{PHASES OF THE PROPOSAL}

The authors propose 5 phases to implement the Lean Plan. First, the project where the intervention will be carried out must be known and characterized; The next step is to make a diagnosis using different KPI's, to establish a baseline; Then, the Lean tools, methods, or approaches are selected (according to the problems detected in the initial diagnosis); Subsequently, the tools, methods, or approaches are applied in each particular case; Finally, evaluate and start a process of continuous improvement, see Figure 2. 


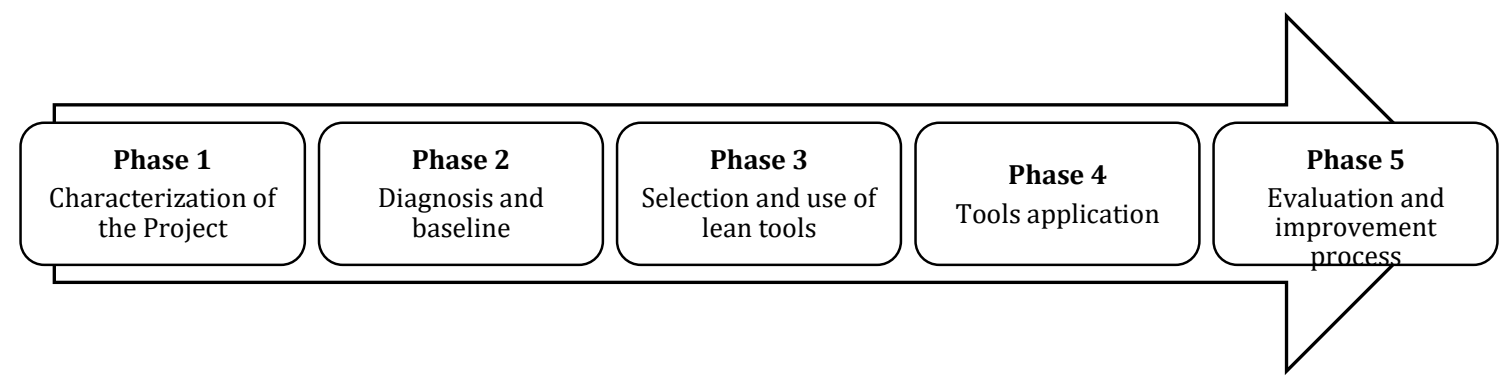

Figure 2: Phases of Lean Implementation Plan

\section{LEAN TOOLS PROPOSAL}

According to the State of Art and Practice, the authors selected the main tools, methods, and approaches of Lean Construction that can mitigate the factors that generate delays and cost increases in construction projects. See Table 1.

Table 1: Main Lean Construction Tools/Methods/Approaches

\begin{tabular}{|c|c|c|}
\hline Tools & Short Definition & References \\
\hline $\begin{array}{l}\text { Last Planner }{ }^{\circledR} \\
\text { System (LPS) }\end{array}$ & $\begin{array}{l}\text { "System for project production planning and control, aimed at } \\
\text { creating a workflow that achieves reliable execution, developed by } \\
\text { Glenn Ballard and Greg Howell. LPS }{ }^{\circledR} \text { is the collaborative, } \\
\text { commitment-based planning system that integrates should-can-will- } \\
\text { did planning: pull planning, make-ready look-ahead planning with } \\
\text { constraint analysis, weekly work planning based upon reliable } \\
\text { promises, and learning based upon analysis of PPC and Reasons for } \\
\text { Variance." }\end{array}$ & $\begin{array}{l}\text { (Lean Construction } \\
\text { Institute 2017) }\end{array}$ \\
\hline $\begin{array}{l}\text { Building } \\
\text { Information } \\
\text { Models (BIM) }\end{array}$ & $\begin{array}{l}\text { "The process of generating and managing building data during the life } \\
\text { cycle of a building. BIM uses three-dimensional (3D), real-time, } \\
\text { dynamic building modeling software. BIM includes building } \\
\text { geometry, spatial relationships, geographic information, and } \\
\text { quantities and properties of building components. BIM can include } \\
\text { four-dimensional or more (4D, 5D, etc.)...BIM provides the platform } \\
\text { for simultaneous conversations related to the design of the "product" } \\
\text { and its delivery process" }\end{array}$ & $\begin{array}{l}\text { (Lean Construction } \\
\text { Institute 2017) }\end{array}$ \\
\hline $\begin{array}{l}\text { Visual } \\
\text { Management } \\
(\mathrm{VM})\end{array}$ & $\begin{array}{l}\text { "Placing tools, parts, production activities, plans, schedules, measures } \\
\text { and performance indicators in plain view, This assures that the status } \\
\text { of the system can be understood at a glance by everyone involved and } \\
\text { actions taken locally in support of system objectives." }\end{array}$ & $\begin{array}{l}\text { (Lean Construction } \\
\text { Institute 2017) }\end{array}$ \\
\hline $\begin{array}{l}\text { Value Stream } \\
\text { Mapping (VSM) }\end{array}$ & $\begin{array}{l}\text { "VSM is a paper and pen tool where a map of the complete process is } \\
\text { drawn out with a set of standardized icons, introduced by Rother and } \\
\text { Shook (1998). With a map of the complete process, it is easier to } \\
\text { analyze and identify any weaknesses or waste sources. Once these are } \\
\text { identified, changes are proposed and implemented and the new } \\
\text { process is evaluated" }\end{array}$ & $\begin{array}{c}\text { (Deffense and } \\
\text { Cachadinha 2011) }\end{array}$ \\
\hline $\begin{array}{l}\text { Integrated Project } \\
\text { Delivery (IPD) }\end{array}$ & $\begin{array}{l}\text { "A project delivery approach that integrates people, systems, business } \\
\text { structures, and practices into a process that collaboratively harnesses } \\
\text { the talents and insights of all participants to reduce waste and optimize } \\
\text { efficiency through all phases of the project, from early design through } \\
\text { project handover" }\end{array}$ & $\begin{array}{l}\text { (Lean Construction } \\
\text { Institute 2017) }\end{array}$ \\
\hline $\begin{array}{l}\text { Target Value } \\
\text { Design (TVD) }\end{array}$ & $\begin{array}{l}\text { "TVD views AEC (Architecture, Engineering and Construction) as a } \\
\text { complex system, which includes the project definition, design and } \\
\text { construction stages. TVD transforms the current design practices } \\
\text { upside down because the costs determine the design instead of the } \\
\text { design determining the costs" }\end{array}$ & (Miron et al. 2015) \\
\hline $\begin{array}{l}\text { Linguistic Action } \\
\text { Perspective }\end{array}$ & $\begin{array}{l}\text { "Linguistic Action Perspective was developed by F. Flores (2015) and } \\
\text { it is basically an application of Speech Act Theory to organizational }\end{array}$ & (Salazar et al. 2018) \\
\hline
\end{tabular}




\begin{tabular}{|c|c|c|}
\hline (LAP) & $\begin{array}{l}\text { management. That conversations do not simply precede action, but } \\
\text { rather constitute actions themselves through the commitments that } \\
\text { emerge... Every conversation for action includes four basic speech } \\
\text { acts: 1) request or offer, 2) promise or acceptance, 3) declaration of } \\
\text { compliance and 4) declaration of satisfaction" }\end{array}$ & (Salazar et al. 2019) \\
\hline $\begin{array}{l}\text { Choosing by } \\
\text { Advantages } \\
\text { (CBA) }\end{array}$ & $\begin{array}{l}\text { "CBA is a tested and effective sound decision-making system } \\
\text { developed by Jim Suhr (1999) for determining the best decision by } \\
\text { looking at the advantages of each option" }\end{array}$ & $\begin{array}{l}\text { (Lean Construction } \\
\text { Institute 2017) }\end{array}$ \\
\hline Gemba Walk & $\begin{array}{l}\text { "Gemba is the Japanese word for "actual place." This concept was } \\
\text { developed in the Lean manufacturing paradigm into the practice of } \\
\text { Gemba walks. It is essential to understand the importance of "go and } \\
\text { see" for the construction process" }\end{array}$ & (Taggart et al. 2019) \\
\hline $5 \mathrm{~S}$ & $\begin{array}{l}\text { "The 5S's are of Japanese origin and are distributed in five actions } \\
\text { aimed at organization and standardization of work. The 5S's of this } \\
\text { methodology are Seiri (Sorting), Seiton (Stabilize), Seiso (Systematic } \\
\text { Cleaning), Seiketsu (Standardizing), and Shitsuke (Sustaining)" }\end{array}$ & $\begin{array}{c}\text { (Deffense and } \\
\text { Cachadinha 2011) }\end{array}$ \\
\hline Just in Time (JIT) & $\begin{array}{l}\text { "A system for producing or delivering the right amount of parts or } \\
\text { product at the time it is needed for production" }\end{array}$ & $\begin{array}{l}\text { (Lean Construction } \\
\text { Institute 2017) }\end{array}$ \\
\hline Kanban & $\begin{array}{l}\text { "Japanese term meaning "a signboard." A communication tool used } \\
\text { in JIT production systems. The signal tells workers to pull parts or } \\
\text { refill material to a certain quantity used in production" }\end{array}$ & $\begin{array}{l}\text { (Lean Construction } \\
\text { Institute 2017) }\end{array}$ \\
\hline A3 Report & $\begin{array}{l}\text { "A one-page report prepared on a single } 11 \times 17 \text { sheet of paper that } \\
\text { adheres to the discipline of PDCA thinking as applied to collaborative } \\
\text { problem solving, strategy development or reporting. The A3 includes } \\
\text { the background, problem statement, analysis, proposed actions, and } \\
\text { the expected results" }\end{array}$ & $\begin{array}{l}\text { (Lean Construction } \\
\text { Institute 2017) }\end{array}$ \\
\hline $\begin{array}{l}\text { Set-Based Design } \\
\text { (SBD) }\end{array}$ & $\begin{array}{l}\text { "A design method whereby sets of alternative solutions to parts of the } \\
\text { problem are kept open until their Last Responsible Moment(s), in } \\
\text { order to find by means of set intersection the best combination that } \\
\text { solves the problem as a whole" }\end{array}$ & $\begin{array}{l}\text { (Lean Construction } \\
\text { Institute 2017) }\end{array}$ \\
\hline Jidoka & $\begin{array}{l}\text { "Concept Japanese, translated as 'autonomation' in English, this form } \\
\text { a pillar of the Toyota Production System. Autonomation refers to } \\
\text { machines built to detect problems and stop by themselves, so as to } \\
\text { "relieve the burden of constantly supervising a machine, and allow } \\
\text { [people] to use their talents for more beneficial things (like adding } \\
\text { value)" (Liker and Meier } 2006 \text { p. 177) }\end{array}$ & (Tommelein 2008) \\
\hline
\end{tabular}

Then, for each one of the identified factors in the first stage, a main Lean construction tool, method, or approach was assigned, considering the possibilities to mitigate their impacts. The results are included in Table 2.

Table 2: Lean Construction Tools/Methods/Approaches assigned to factors

\begin{tabular}{clll}
\hline & Group & Factors (problems) & Main Lean tool \\
\hline 1 & Design & Design changes & Set-Based Design (SBD) \\
2 & & Design errors & Set-Based Design (SBD) \\
3 & & Preparation/ Approval of designs & Building Information Models \\
(BIM) \\
4 & & Extent of completion of pre contract design & Set-Based Design (SBD) \\
\hline 5 & Project & Contractor's financial problems & -- \\
6 & & Nonperformance / problems subcontractors & Linguistic Action Perspective \\
7 & & Subcontractor's financial problems & -- \\
8 & & Low speed of decision making & Choosing by Advantages (CBA) \\
9 & & Poor planning and scheduling & Last Planner® System (LPS) \\
10 & & Poor site management/ supervision & Gemba Walk
\end{tabular}




\begin{tabular}{|c|c|c|c|}
\hline 11 & & Poor management of contractors' schedules & Last Planner ${ }^{\circledR}$ System (LPS) \\
\hline 12 & & $\begin{array}{l}\text { Lack of } \\
\text { coordination/communication/integration }\end{array}$ & $\begin{array}{l}\text { Linguistic Action Perspective } \\
\text { (LAP) }\end{array}$ \\
\hline 13 & & Low level of professional skills & -- \\
\hline 14 & & Complexity of works & Value Stream Mapping (VSM) \\
\hline 15 & & Poor technical performance & Jidoka \\
\hline 16 & & Poor project management assistance & Visual Management (VM) \\
\hline 17 & & Delay in performing inspection and testing & Jidoka \\
\hline 18 & & $\begin{array}{l}\text { Improper control over site resource } \\
\text { allocations }\end{array}$ & $5 \mathrm{~s}$ \\
\hline 19 & & Methods/techniques of construction & Value Stream Mapping (VSM) \\
\hline 20 & & $\begin{array}{l}\text { Contractor's deficiencies in planning and } \\
\text { scheduling at tender stage }\end{array}$ & Last Planner® System (LPS) \\
\hline 21 & & Shortage of contractors & Integrated Project Delivery (IPD) \\
\hline 22 & & Consultant recruitment delay & Last Planner® System (LPS) \\
\hline 23 & & Project staff hiring delay & Last Planner ${ }^{\circledR}$ System (LPS) \\
\hline 24 & & Tendency to pass on the blame to others & $\begin{array}{l}\text { Linguistic Action Perspective } \\
\text { (LAP) }\end{array}$ \\
\hline 25 & & Conflict between project parties & Integrated Project Delivery (IPD) \\
\hline 26 & & Resumption/accommodation works & $\begin{array}{l}\text { Building Information Models } \\
\text { (BIM) }\end{array}$ \\
\hline 27 & & Project administration cost increase & Integrated Project Delivery (IPD) \\
\hline 28 & & Remote location costs & -- \\
\hline 29 & & Quantity increased measure & $\begin{array}{l}\text { Building Information Models } \\
\text { (BIM) }\end{array}$ \\
\hline 30 & & Poor contract management & Integrated Project Delivery (IPD) \\
\hline 31 & & Schedule delays & Last Planner® System (LPS) \\
\hline 32 & & Contractor risk's management & Integrated Project Delivery (IPD) \\
\hline 33 & External & Environmental impacts mitigation & Choosing by Advantages (CBA) \\
\hline 34 & aspects & Weather & A3 Report \\
\hline 35 & & Natural calamities & A3 Report \\
\hline 36 & & Unforeseen ground conditions & A3 Report \\
\hline 37 & & Works in conflict with existing utilities & $\begin{array}{l}\text { Building Information Models } \\
\text { (BIM) }\end{array}$ \\
\hline 38 & $\begin{array}{l}\text { Owner } \\
\text { management }\end{array}$ & Financial difficulties by the owner & $\begin{array}{l}\text { Target Value Design } \\
\text { (TVD) }\end{array}$ \\
\hline 39 & & Errors in bidding and award & $\begin{array}{l}\text { Integrated Project } \\
\text { Delivery (IPD) }\end{array}$ \\
\hline 40 & & Delays in decision making & $\begin{array}{l}\text { Choosing by Advantages } \\
\text { (CBA) }\end{array}$ \\
\hline 41 & & Inexperienced contractor/ consultant & $\begin{array}{l}\text { Building Information } \\
\text { Models (BIM) }\end{array}$ \\
\hline 42 & & $\begin{array}{l}\text { Insufficient feasibility studies and survey } \\
\text { before investment }\end{array}$ & Set-Based Design (SBD) \\
\hline 43 & & Duration of contract period & $\begin{array}{l}\text { Target Value Design } \\
\text { (TVD) }\end{array}$ \\
\hline 44 & & Burocracy/ Inneficient internal processes & $\begin{array}{l}\text { Value Stream Mapping } \\
\text { (VSM) }\end{array}$ \\
\hline 45 & & Delays in progress payment & $\begin{array}{l}\text { Last Planner® System } \\
\text { (LPS) }\end{array}$ \\
\hline 46 & & Change orders/ scope change & Set-Based Design (SBD) \\
\hline 47 & & Land acquisition delay/ Late site delivery & $\begin{array}{l}\text { Last Planner® System } \\
\text { (LPS) }\end{array}$ \\
\hline 48 & & Ambiguous/errors contract information & $\begin{array}{l}\text { Integrated Project } \\
\text { Delivery (IPD) }\end{array}$ \\
\hline
\end{tabular}




\begin{tabular}{|c|c|c|c|}
\hline 49 & & Partial payments during construction & $\begin{array}{l}\text { Integrated Project } \\
\text { Delivery (IPD) }\end{array}$ \\
\hline 50 & & $\begin{array}{l}\text { Non utilization of professional } \\
\text { construction/contractual management }\end{array}$ & -- \\
\hline 51 & & Underestimation of time for completion & $\begin{array}{l}\text { Last Planner }{ }^{\circledR} \text { System } \\
\text { (LPS) }\end{array}$ \\
\hline 52 & & Underestimation of cost projects & $\begin{array}{l}\text { Target Value Design } \\
\text { (TVD) }\end{array}$ \\
\hline 53 & & $\begin{array}{l}\text { Inadequate definition of substantial } \\
\text { completion }\end{array}$ & $\begin{array}{l}\text { Target Value Design } \\
\text { (TVD) }\end{array}$ \\
\hline 54 & & Noncompliance with conditions of contract & $\begin{array}{l}\text { Building Information } \\
\text { Models (BIM) }\end{array}$ \\
\hline 55 & & Inadequate cost estimating approach & $\begin{array}{l}\text { Target Value Design } \\
\text { (TVD) }\end{array}$ \\
\hline 56 & Resources & Shortage of labors & Kanban \\
\hline 57 & & Unqualified work force/ productivity & Gemba Walk \\
\hline 58 & & Shortage of materials & Just in Time (JIT) \\
\hline 59 & & $\begin{array}{l}\text { Delay in material to be supplied by the } \\
\text { owner }\end{array}$ & Just in Time (JIT) \\
\hline 60 & & Material procurement/delays & Just in Time (JIT) \\
\hline 61 & & $\begin{array}{l}\text { Delay in material procurement (by the } \\
\text { contractor) }\end{array}$ & Just in Time (JIT) \\
\hline 62 & & Delay in approving sample materials & $\begin{array}{l}\text { Last Planner® System } \\
\text { (LPS) }\end{array}$ \\
\hline 63 & & $\begin{array}{l}\text { Poor interaction with vendors in the } \\
\text { engineering and procurement stages }\end{array}$ & $\begin{array}{l}\text { Target Value Design } \\
\text { (TVD) }\end{array}$ \\
\hline 64 & & Shortage of fuel & Just in Time (JIT) \\
\hline 65 & & Shortage of foreign currency & Just in Time (JIT) \\
\hline 66 & & Poor quality of equipment & $\begin{array}{l}\text { Choosing by Advantages } \\
\text { (CBA) }\end{array}$ \\
\hline 67 & & Shortage of equipment & Just in Time (JIT) \\
\hline 68 & Government & Government pressures/ policies & -- \\
\hline 69 & / society & Strikes & $\begin{array}{l}\text { Linguistic Action } \\
\text { Perspective (LAP) }\end{array}$ \\
\hline 70 & & Government procedural delay/ permissions & $\begin{array}{l}\text { Last Planner® System } \\
\text { (LPS) }\end{array}$ \\
\hline 71 & & Society concerns & $\begin{array}{l}\text { Linguistic Action } \\
\text { Perspective (LAP) }\end{array}$ \\
\hline 72 & & Public Order Situation & -- \\
\hline 73 & & Political situation & -- \\
\hline 74 & & Inflation/ Economic problems & -- \\
\hline
\end{tabular}

Finally, the authors emphasize that each factor can be mitigated by more than one Lean tool. Therefore, Table 3 shows the factors that could be mitigated by each selected Lean tool, method, or approach. 
Table 3: Lean Construction Tools features

\begin{tabular}{|c|c|}
\hline Lean Tools, Methods \& Approaches & Time and cost deviations factor \\
\hline BIM & $\begin{array}{l}1,2,3,8,9,10,11,12,14,16,19,20,22,23,24,25,26,27, \\
29,30,31,32,33,36,37,38,39,40,41,42,43,44,45,46, \\
48,51,52,53,54,55,60,61,62,63,70\end{array}$ \\
\hline Set-Based Design (SBD) & $\begin{array}{l}1,2,3,4,9,11,12,14,16,19,20,21,22,23,24,25,26,27, \\
29,30,31,32,33,36,37,38,39,40,41,42,43,44,45,46, \\
47,48,51,52,53,54,55,60,61,62,63,70\end{array}$ \\
\hline Linguistic Action Perspective (LAP) & $\begin{array}{l}6,9,12,18,24,25,26,27,31,40,41,44,45,46,53,60,61, \\
62,63,69,70,71\end{array}$ \\
\hline Choosing by Advantages (CBA) & $\begin{array}{l}2,3,8,9,12,14,18,19,20,21,22,23,24,25,29,30,31 \\
32,33,36,37,38,39,40,41,42,43,44,46,47,48,51,52 \\
53,54,55,62,63,64,65,66,70,71\end{array}$ \\
\hline Last Planner® System (LPS) & $\begin{array}{l}6,9,10,11,12,14,18,20,21,22,23,24,25,26,27,30,31, \\
34,35,40,43,44,45,46,47,51,56,58,59,60,61,62,64, \\
66,67,70\end{array}$ \\
\hline Gemba Walk & $\begin{array}{l}9,10,12,14,17,18,19,25,26,31,34,35,40,45,46,56, \\
57,58,59,60,61,62,63,66,67\end{array}$ \\
\hline Jidoka & $\begin{array}{l}10,14,15,17,18,20,29,30,31,32,33,37,38,39,40,41 \\
42,43,44,45,46,48,51,52,55,62,63,70\end{array}$ \\
\hline Visual Management (VM) & $\begin{array}{l}1,2,3,8,9,12,14,16,18,19,20,24,26,29,30,31,32,33, \\
36,37,38,39,40,41,42,43,44,45,46,47,48,51,52,53, \\
54,55,59,60,61,62,63,67,70\end{array}$ \\
\hline Integrated Project Delivery (IPD) & $\begin{array}{l}1,2,3,8,9,11,12,14,16,19,20,21,22,23,24,25,26,27, \\
29,30,31,32,33,36,37,38,39,40,41,42,43,44,45,46, \\
47,48,49,51,52,53,54,55,62,63,70\end{array}$ \\
\hline A3 Report & $1,2,3,17,18,34,35,36,38,40,42,44,56$ \\
\hline Target Value Design (TVD) & $\begin{array}{l}1,2,3,9,19,22,23,24,25,26,27,29,30,31,32,38,39 \\
40,41,42,43,44,45,46,48,49,51,52,53,54,55,64,65 \\
70\end{array}$ \\
\hline Just in Time (JIT) & $21,22,58,59,60,61,62,63,64,65,66,67$ \\
\hline
\end{tabular}

\section{CONCLUSIONS}

In this research, a literature review has been developed in two topics, factors causing time and cost deviations and lean tools, methods, and approaches applicable to construction projects. Although it has been focused on the Web of Science database, building and infrastructure projects have been included in the first stage to have global information.

The analysis developed in this research allowed assigning a lean mitigation tool, method, or approach for $87.84 \%$ of the factors. The factors on which it was not possible to assign lean tools, methods, or approaches corresponded to those related to financial aspects, to aspects of professional and workers training and factors like political or social situation, problems with inflation. On the other hand, there are factors that can be mitigated with two or more tools, for example, the meteorological factor; it can be considered a constraint in the Last Planner System and then determine the best solution through an $\mathrm{A} 3$ report.

The literature review allowed developing an in-depth analysis of the research related to factors causing delays and cost overruns in construction projects and lean tools, methods, and approaches applicable to the construction industry. Both have been a subject of interest among authors who have developed an important body of literature, and for this reason, it is proposed the integration. Future research may focus on demonstrating the effectiveness of the lean tools, methods, and approaches discussed in this article. 


\section{ACKNOWLEDGMENTS}

Luis A. Salazar acknowledges the financial support for his $\mathrm{PhD}$ studies from the Scholarship Programme of National Agency for Research and Development of Chile (ANID-PCHA/Doctorado Nacional/2016-21160819)

\section{REFERENCES}

Abd El-Razek, M. E., Bassioni, H. A., and Mobarak, A. M. (2008). "Causes of Delay in Building Construction Projects in Egypt." Journal of Construction Engineering and Management, 134(11), 831-841.

Ahsan, K., and Gunawan, I. (2010). "Analysis of cost and schedule performance of international development projects." International Journal of Project Management, 28(1), 68-78.

Aibinu, A. A., and Odeyinka, H. A. (2006). "Construction Delays and Their Causative Factors in Nigeria." Journal of Construction Engineering and Management, 132(7), 667-677.

Akogbe, R.-K. T. M., Feng, X., and Zhou, J. (2013). "Importance and ranking evaluation of delay factors for development construction projects in Benin." KSCE Journal of Civil Engineering, 17(6), 1213-1222.

Arroyo, P., Christensen, R., Schöttle, A., and Long, D. (2019). "Lessons Learned on Teaching Choosing by Advantages." Proc. 27th Annual Conference of the International Group for Lean Construction (IGLC), Dublin, Ireland, 405-416.

Assaf, S. A., Al-Khalil, M., and Al-Hazmi, M. (1995). "Causes of Delay in Large Building Construction Projects." Journal of Management in Engineering, 11(2), 4550.

Bagaya, O., and Song, J. (2016). "Empirical Study of Factors Influencing Schedule Delays of Public Construction Projects in Burkina Faso." Journal of Management in Engineering, American Society of Civil Engineers, 32(5), 05016014.

Batool, A., and Abbas, F. (2017). "Reasons for delay in selected hydro-power projects in Khyber Pakhtunkhwa (KPK), Pakistan.” Renewable and Sustainable Energy Reviews, 73, 196-204.

Castiblanco, F. M., Castiblanco, I. A., and Cruz, J. P. (2019). "Qualitative analysis of lean tools in the construction sector in Colombia." Proc. 27th Annual Conference of the International. Group for Lean Construction (IGLC), Pasquire. C and Hamzeh. FR, ed., Dublin, Ireland, 1023-1036.

Chan, D. W. M., and Kumaraswamy, M. M. (1996). "An evaluation of construction time performance in the building industry." Building and Environment, 31(6), 569-578.

Chiu, B. W. Y., and Lai, J. H. K. (2017). "Project delay: key electrical construction factors in Hong Kong." Journal of Civil Engineering and Management, 23(7), 847-857.

Creedy, G. D., Skitmore, M., and Wong, J. K. W. (2010). "Evaluation of Risk Factors Leading to Cost Overrun in Delivery of Highway Construction Projects." Journal of Construction Engineering and Management, 136(5), 528-537.

Deffense, J., and Cachadinha, N. (2011). "Lean Production in the precast concrete components' industry." Proc. 19th Annual Conference of the International Group for Lean Construction (IGLC), Lima, Perú.

Derakhshanalavijeh, R., and Teixeira, J. M. C. (2017). "Cost overrun in construction projects in developing countries, gas-oil industry of Iran as a case study." Journal of Civil Engineering and Management, 23(1), 125-136. 
Doloi, H. (2013). "Cost Overruns and Failure in Project Management: Understanding the Roles of Key Stakeholders in Construction Projects." Journal of Construction Engineering and Management, 139(3), 267-279.

Doloi, H., Sawhney, A., Iyer, K. C., and Rentala, S. (2012). "Analysing factors affecting delays in Indian construction projects." International Journal of Project Management, 30(4), 479-489.

Elinwa, A. U., and Joshua, M. (2001). "Time-Overrun Factors in Nigerian Construction Industry." Journal of Construction Engineering and Management, 127(5), 419-425.

Fallahnejad, M. H. (2013). "Delay causes in Iran gas pipeline projects." International Journal of Project Management, 31(1), 136-146.

Farzad, M. R., and Cameron, V. A. (2019). "Implementing Lean Visual Tools on the Closeout Phase of a Globalscale Industrial Project." Proc. 27th Annual Conference of the International Group for Lean Construction (IGLC), Dublin, Ireland, 675-686.

Flyvbjerg, B., Holm, M. S., and Buhl, S. (2002). "Underestimating Costs in Public Works Projects: Error or Lie?" Journal of the American Planning Association, 68(3), 279295.

Giménez, Z., Mourgues, C., Alarcón, L. F., and Mesa, H. (2019). "Proposal of a Model for Measuring Value in the Design Process." Proc. 27th Annual Conference of the International Group for Lean Construction (IGLC), Dublin, Ireland, 49-62.

Gómez-Cabrera, A., Ponz-Tienda, J. L., Pellicer, E., and Sanz, A. (2019). "Factors Generating Schedule Delays and Cost Overruns in Construction Projects." VIII Encuentro Latinoamericano de Gestión Y Economía de la Construcción, Londrina, Brasil.

Gómez-Sánchez, J. M., Ponz-Tienda, J. L., and Romero-Cortés, J. P. (2019). "Lean and BIM Implementation in Colombia; Interactions and Lessons Learned." Proc. 27th Annual Conference of the International Group for Lean Construction (IGLC), Dublin, Ireland, 1117-1128.

Gunduz, M., Nielsen, Y., and Ozdemir, M. (2013). "Quantification of Delay Factors Using the Relative Importance Index Method for Construction Projects in Turkey." Journal of Management in Engineering, 29(2), 133-139.

Gunduz, M., Nielsen, Y., and Ozdemir, M. (2015). "Fuzzy Assessment Model to Estimate the Probability of Delay in Turkish Construction Projects." Journal of Management in Engineering, 31(4), 04014055.

Hackler, C., Byse, E., Alves, T. da C. L., and Reed, D. (2019). "Building a Lean Culture: Engaging the Value Stream." Proc. 27th Annual Conference of the International Group for Lean Construction (IGLC), Dublin, Ireland, 169-178.

Iyer, K. C., and Jha, K. N. (2006). "Critical Factors Affecting Schedule Performance: Evidence from Indian Construction Projects." Journal of Construction Engineering and Management, 132(8), 871-881.

Kaliba, C., Muya, M., and Mumba, K. (2009). "Cost escalation and schedule delays in road construction projects in Zambia." International Journal of Project Management, 27(5), 522-531.

Kamanga, M., and Steyn, W. (2013). "Causes of Delay in Road Construction Projects in Malawi." Journal of The South African Institution of Civil Engineering, 55(3), 79-85.

Kazaz, A., Ulubeyli, S., and Tuncbilekli, N. A. (2012). "Causes of delays in construction projects in Turkey." Journal of Civil Engineering and Management, 18(3), 426-435. 
Kim, S.-Y., Tuan, K. N., Lee, J. Do, Pham, H., and Luu, V. T. (2017). "Cost overrun factor analysis for hospital projects in Vietnam." KSCE Journal of Civil Engineering, 22(1), 1-11.

Kitchenham, B. (2010). "What's up with software metrics? - A preliminary mapping study." The Journal of Systems \& Software, Elsevier Inc., 83(1), 37-51.

Larsen, J. K., Shen, G. Q., Lindhard, S. M., and Brunoe, T. D. (2016). "Factors Affecting Schedule Delay, Cost Overrun, and Quality Level in Public Construction Projects." Journal of Management in Engineering, 32(1), 04015032.

Le-Hoai, L., Lee, Y. D., and Lee, J. Y. (2008). "Delay and cost overruns in Vietnam large construction projects: A comparison with other selected countries." KSCE Journal of Civil Engineering, 12(6), 367-377.

Lo, T. Y., Fung, I. W., and Tung, K. C. (2006). "Construction Delays in Hong Kong Civil Engineering Projects." Journal of Construction Engineering and Management, 132(6), 636-649.

Love, P., Wang, X., Sing, C., and Tiong, R. L. K. (2013). "Determining the Probability of Project Cost Overruns." Journal of Construction Engineering and Management, 139(3), 321-330.

Mahamid, I., Bruland, A., and Dmaidi, N. (2012). "Causes of Delay in Road Construction Projects." Journal of Management in Engineering, 28(3), 300-310.

Miron, L. I. G., Kaushik, A., and Koskela, L. (2015). "Target Value Design: The challenge of value generation." Proc. 23th Annual Conference of the International Group for Lean Construction (IGLC), Perth, Australia, 815-825.

Mpofu, B., Ochieng, E. G., Moobela, C., and Pretorius, A. (2017). "Profiling causative factors leading to construction project delays in the United Arab Emirates." Engineering, Construction and Architectural Management, 24(2), 346-376.

Okpala, D. C., and Aniekwu, A. N. (1988). "Causes of High Costs of Construction in Nigeria." Journal of Construction Engineering and Management.

Ruqaishi, M., and Bashir, H. A. (2015). "Causes of Delay in Construction Projects in the Oil and Gas Industry in the Gulf Cooperation Council Countries : A Case Study." Journal of Management in Engineering, 31(3), 1-8.

Ryan, M., Murphy, C., and Casey, J. (2019). "Case Study in the Application of the Last Planner ${ }^{\circledR}$ System." Proc. 27th Annual Conference of the International Group for Lean Construction (IGLC), Dublin, Ireland, 215-226.

Salazar, L. A., Ballard, G., Arroyo, P., and Alarcón, L. F. (2018). "Indicators for Observing Elements of Linguistic Action Perspective in Last Planner ${ }^{\circledR}$ System." Proc. 26th Annual Conference of the International. Group for Lean Construction (IGLC), V. A. González, ed., Chennai, India, 402-411.

Salazar, L. A., Retamal, F., Ballard, G., Arroyo, P., and Alarcón, L. F. (2019). "Results of indicators from the Linguistic Action Perspective in the Last Planner(r) System." Proc. 27th Annual Conference of the International Group for Lean Construction (IGLC), Pasquire C. and Hamzeh F.R., ed., Dublin, Ireland, 1241-1250.

Sambasivan, M., Deepak, T. J., Salim, A. N., and Ponniah, V. (2017). "Analysis of delays in Tanzanian construction industry." Engineering, Construction and Architectural Management, 24(2), 308-325.

Santoso, D. S., and Soeng, S. (2016). "Analyzing Delays of Road Construction Projects in Cambodia: Causes and Effects." Journal of Management in Engineering, 32(6), 05016020 . 
Shahsavand, P., Marefat, A., and Parchamijalal, M. (2018). "Causes of delays in construction industry and comparative delay analysis techniques with SCL protocol." Engineering, Construction and Architectural Management, 25(4), 497-533.

Skaar, J. (2019). "The Power of Lean Principles." Proc. 27th Annual Conference of the International Group for Lean Construction (IGLC), Dublin, Ireland, 393-404.

Taggart, M., Willis, C., and Hanahoe, J. (2019). "Not seeing the wood for the trees - a Gemba Walk through a timber framed housing development." Proc. 27th Annual Conference of the International. Group for Lean Construction (IGLC), Pasquire C. and Hamzeh F.R., ed., Dublin, Ireland, 1209-1218.

Tommelein, I. D. (2008). "Poka Yoke' or Quality by mistake proofing design and construction systems." Proc. 16th Annual Conference of the International. Group for Lean Construction (IGLC), Manchester, UK, 195-205.

Vallejo-Borda, J. A., Gutierrez-Bucheli, L. A., Pellicer, E., and Ponz-Tienda, J. L. (2015). "Behavior in Terms of Delays and Cost Overrun of the Construction of Public Infrastructure in." Sibragec Elagec 2015, 66-73.

Wang, T.-K., Ford, D. N., Chong, H.-Y., and Zhang, W. (2018). "Causes of delays in the construction phase of Chinese building projects." Engineering, Construction and Architectural Management, 25(11), 1534-1551. 